\title{
Cost- Benefit Analysis of Urban Water Supply and Distribution Scheme
}

\author{
IBEJE, AO \\ Department of Civil Engineering, Imo State University, P.M.B. 2000, Owerri, Nigeria \\ Author Email: engineeribeje@yahoo.com
}

\begin{abstract}
In this study, cost-benefit analysis of Awka city water supply project was carried out considering current and projected water supply infrastructure. The result indicates benefit-cost ratios ranging from 0.3 to 0.5 , meaning that there are between $\$ 1.90$ and $\$ 3.36$ of costs for every $\$ 1$ in economic benefits. When these very low benefit-cost ratios are considered alongside the inconsistent and incomplete financial plans, it is clear that the proposed water supply project is not justified on an economic or financial basis. The study revealed that investments in the proposed water supply project would reduce government expenditure by over a period of twenty years.
\end{abstract}

\section{DOI: $\underline{\text { https://dx.doi.org/10.4314/jasem.v23i2.25 }}$}

Copyright: Copyright (C) 2019 Ibeje. This is an open access article distributed under the Creative Commons Attribution License (CCL), which permits unrestricted use, distribution, and reproduction in any medium, provided the original work is properly cited.

Dates: Received: 17 November 2018; Revised: 19 January 2019; Accepted 22 January 2019

Keywords: water; supply; project; cost-benefit; analysis

In the past, protection of human health and the natural environment did not seem to require economic analysis. Before the 1980s, public health and environmental policies were debated primarily on scientific, ethical, and legal grounds, with less emphasis on costs; let alone monetized benefits Cole and Elliot (2007). More recently, it has become the norm to assume the need for cost-benefit analysis of new policies, comparing monetary costs and estimates of the monetary value of benefits. Just as a business should only make an investment if the expected revenues exceed the costs, the new approach suggests that government should only adopt a new initiative if its expected benefits exceed its costs. Ackerman (2006) reported the applications of cost-benefit analysis in water projects. Benefit-cost analysis examines a full stream of costs and benefits over the expected life of the project. The absence of benefitcost analysis throughout the intended water supply project is a significant weakness that has left policy makers poorly informed to make a decision about a very costly investment with far reaching economic effects (Pearce, 1998). The water supply schemes at rivers Imo-Awka, Uvunu, Amawbia, Obibia and Okika spring as well as water borehole sites at Amawbia have failed to meet the water demands of the people. Almost all the above mentioned schemes have all broken down completely (Emesin, 2000).The Anambra State government embarked upon redesigning and expansion of the Awka water supply infrastructure. This was aimed at the ever increasing water needs of Awka city. The economic viability of the new water supply policy has become a subject of debate. This calls for an engineering approach in terms of benefit-cost analysis to establish the economic relevance of the expansion of Awka water supply infrastructure. The intention of this study is to conduct comprehensive benefit-cost analysis, and to provide appropriate economic justification of the project. Benefit-cost analysis is conducted and refined throughout a planning process that yields valuable insights about a projects strengths, weaknesses, and overall merit.

\section{MATERIALS AND METHODS}

Awka has a typical climate with an average yearly rainfall of $1478 \mathrm{~mm}$ (Okpoka, 1983) and mean temperature of $27^{\circ} \mathrm{C}$. Rainfall recorded for Awka town from 1981 - 1984 ranges from $1343 \mathrm{~mm}-1884 \mathrm{~mm}$. The area covers $500 \mathrm{~km}^{2}$ and lies between latitude $6^{0}$ $06^{1}$ and $6^{0} 17^{1} \mathrm{~N}$ and longitude $6^{0} 59^{1}$ and $7^{0} 11^{1} \mathrm{E}$. The geological formations underlying the area include the Nanka sands, lfite sands, Isiagu sands; Ebenebe sandstone and the Imo shale formation (Okpoko, 1983). The surface waters have their sources in the sand stone unit and flow out into the shale terrain. Information obtained from Anambra State Water Corporation (ASWC) includes water quality, discharge, stream flow safe yield and sustainability in rainy and dry seasons of sources of surface water in Awka. The surface waters visited were: rivers ImoAwka, Uvunu, Amawbia, Obibia and Okika spring. 
Borehole sites at Amawbia were visited to ascertain functionality, borehole type, rate of recharge, size of drawdown and quality. The existing water schemes were evaluated for 25 years at $5 \%$ to $11 \%$ odd discount rate (Ackerman and Finlayson, 2006).

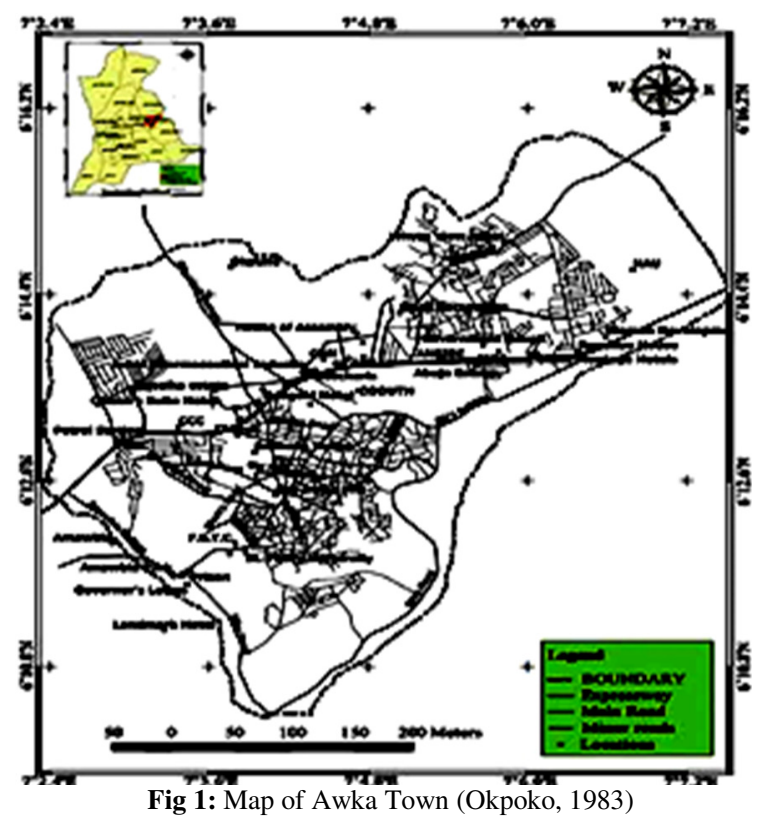

Cost-Benefit Analysis (CBA): The costs and benefits for each year of the project life cycle were estimated and transformed to their "present value." The present value (also referred to as the discounted value) of a future amount was calculated according to Ackerman (2007):

$P=F\left(\frac{1}{(1+I)^{n}}\right)$

Where $\mathrm{P}=$ present value, $\mathrm{F}=$ future value, $\mathrm{I}=$ interest rate, and $\mathrm{n}=$ number of years.

The costs and benefits for each competing alternative were discounted, compared and ranked according to the discounted net value (discounted benefit minus discounted cost) of the competing alternatives. When the alternative with the lowest discounted cost provided the highest discounted benefits, it was recommended the best alternative. The following assumptions for cost-benefit analysis were made. (i) The Project life is 25years, which is the time at which the project reaches its majority, even though the economic benefits extend to a century; (ii) The investment stream in the economic analysis comprises of initial fixed investment; operation and maintenance costs, including annual pumping energy cost and (iii) This analysis used scenarios between $5 \%$ and $11 \%$ discount rate.
Sensitivity analysis tests the sensitivity and reliability of the results obtained from the cost-benefit analysis. Sensitivity analysis identified those input parameters that have the greatest influence on the outcome, repeats the analysis with different input parameter values, and evaluates the results to determine which, if any, input parameters are sensitive. The sensitivity of a project was measured by 'a sensitivity indicator' as given by Pearce (1998):

$$
S=\frac{\left(N P V_{b}-N P V_{I}\right) / N P V_{b}}{\left(X_{b}-X_{I}\right) / X_{b}}
$$

Where $S=$ Sensitivity indicator; $\mathrm{NPV}_{\mathrm{b}}=$ Value of NPV in the base case; $\mathrm{NPV}_{\mathrm{s}}=$ Value of NPV in the sensitivity test $X_{b}=$ Value of a key variable in the base case $; X_{s}=$ Value of a key variable in the sensitivity test

The higher the value of the sensitivity indicator, the more likely that the NPV is subject to changes in the variables concerned, and therefore the higher the risk for the project. It was examined whether the sign of the net benefit value changes from positive to negative when values of key variables are changed. Ackerman and Heinzerling (2004) reported that if the sign did not change, then the cost-benefit analysis of the project is sound and there is greater confidence in its results.

\section{RESULTS AND DISCUSSION}

Tables 1 and 2 show the respective features of the existing and proposed projects. In Tables 3 , the basic cost elements for estimation of the project costs. With a projected population of 304,500 a bigger reservoir capacity was projected to accommodate the additional water demand. The estimated benefits are reported in Table 4 with Imo-Awka River generating most of the benefits and Amabia borehole accounting for the least benefit. Data matrix for both costs and benefits are shown in Tables 5 and 6 . These were the values used in the analysis.

Table 1: Features of Existing Project

\begin{tabular}{ll} 
Design Population (1998) & 130664 \\
River Intake Volume & $1092 \mathrm{~m}^{3}$ \\
Amenyi Reservoir Volume & $1000 \mathrm{~m}^{3}$ \\
Eziakwa Reservoir Volume & $1000 \mathrm{~m}^{3}$ \\
Overhead Tank Volume & $2000 \mathrm{~m}^{3}$ \\
Imo-Awka River Supply & $0.9086 \mathrm{~m}^{3} / \mathrm{s}$ \\
Ifite Stream & $150.03 \mathrm{~m}^{3} / \mathrm{hr}$ \\
Okika River & $29.21 \mathrm{~m}^{3} / \mathrm{hr}$ \\
Amabia Borehole & $27.81 \mathrm{~m}^{3} / \mathrm{hr}$ \\
\hline
\end{tabular}

Table 2: Features of Proposed Project Design Population (2018) 304500 River Intake Volume $\quad 4251 \mathrm{~m}^{3}$ Amenyi Reservoir Volume $\quad 1160 \mathrm{~m}^{3}$ Eziakwa Reservoir Volume $\quad 1160 \mathrm{~m}^{3}$ Water Demand $\quad 55,000 \mathrm{~m}^{3} / \mathrm{s}$ 
Table 3: Basic Cost Elements

\begin{tabular}{ll}
\hline Cost Category & Cost Elements \\
Physical Facilities & Storage tanks, intakes, distribution pipes \\
Equipment & Water pumps, valves \\
Personnel & Salaries of workers \\
Services & Operation and maintenance \\
\hline
\end{tabular}

of piping, borehole operation and pumping energy. This is evaluated over the project design life with the maximum cost generated at the year (1998) of project construction whereas those of the following years remained constant at a value of $\$ 50,153,975$.

Table 6 shows the cost data matrix which is generated from the sum of construction cost of intake tank, cost

Table 4: Estimation of Benefits

\begin{tabular}{llll}
\hline Sources of Benefits & $\begin{array}{l}\text { Quantity of Water } \\
\text { Supplied }\left(\mathrm{m}^{3} / \text { year }\right)\end{array}$ & $\begin{array}{l}\text { Water Rate } \\
\left(\mathrm{N} 0.01 / \mathrm{m}^{3}\right)\end{array}$ & $\begin{array}{l}\text { Annual Benefits } \\
(\mathrm{N})\end{array}$ \\
\hline Imo-Awka River & $28.276 \times 10^{6}$ & 0.01 & $282,760,000$ \\
Ifiet Spring & $1,067,775$ & 0.01 & $10,677.75$ \\
Okika River & 105,720 & 0.01 & $1,057.2$ \\
Amabia Borehole & 89110 & 0.01 & 891.1 \\
Total Annual Benefits & & & $282,772,626.1$ \\
\hline Average Pumping Duration $=$ 20hours/day $\left(\mathrm{N} 0.01 / \mathrm{m}^{3}\right)^{*}$ Source : Ibeje et al., 2012
\end{tabular}

Table 5: Cost Data Matrix

\begin{tabular}{lllllll}
\hline Year & $\begin{array}{l}\text { Cost of Intake Tank } \\
\text { Construction (N) }\end{array}$ & $\begin{array}{l}\text { Cost of Piping } \\
(\mathrm{N})\end{array}$ & $\begin{array}{l}\text { Borehole Operation } \\
\text { and Maintenance } \\
\text { Cost(寻) }\end{array}$ & $\begin{array}{l}\text { Annual Cost } \\
\text { of Pumping } \\
(\mathrm{N})\end{array}$ & $\begin{array}{l}\text { Total Per Year (N) } \\
\text { Post }\end{array}$ \\
\hline 1998 & $50,213,400$ & $336,368,460.8$ & 916,296 & - & $448,541,340$. \\
& & - & & & 8 \\
1999 & - & - & 916,296 & - & 916,296 \\
2000 & - & - & 916,296 & $49,237,679$ & $50,153,975$ \\
2001 & - & 916,296 & $49,237,679$ & $50,153,975$ \\
2002 & - & - & 916,296 & $49,237,679$ & $50,153,975$ \\
2003 & - & - & 916,296 & $49,237,679$ & $50,153,975$ \\
2004 & - & - & 916,296 & $49,237,679$ & $50,153,975$ \\
2005 & - & - & 916,296 & $49,237,679$ & $50,153,975$ \\
2006 & - & - & 916,296 & $49,237,679$ & $50,153,975$ \\
2007 & - & - & 916,296 & $49,237,679$ & $50,153,975$ \\
2008 & - & - & 916,296 & $49,237,679$ & $50,153,975$ \\
2009 & - & - & 916,296 & $49,237,679$ & $50,153,975$ \\
2010 & - & - & 916,296 & $49,237,679$ & $50,153,975$ \\
2011 & - & - & 916,296 & $49,237,679$ & $50,153,975$ \\
2012 & - & - & 916,296 & $49,237,679$ & $50,153,975$ \\
2013 & - & - & 916,296 & $49,237,679$ & $50,153,975$ \\
2014 & - & - & 916,296 & $49,237,679$ & $50,153,975$ \\
2015 & - & - & 916,296 & $49,237,679$ & $50,153,975$ \\
2016 & - & - & 916,296 & $49,237,679$ & $50,153,975$ \\
2017 & - & - & 916,296 & $49,237,679$ & $50,153,975$ \\
2018 & - & - & 916,296 & $49,237,679$ & $50,153,975$ \\
2019 & - & - & 916,296 & $49,237,679$ & $50,153,975$ \\
2020 & - & - & 916,296 & $49,237,679$ & $50,153,975$ \\
2021 & - & - & 916,296 & $49,237,679$ & $50,153,975$ \\
2022 & - & - & 916,296 & $49,237,679$ & $50,153,975$ \\
\hline
\end{tabular}

Table 6 shows the benefit data matrix gotten from different benefit sources as captured in Table 4. The years 1998 and 1999, which are the years of project commencement, generated no benefits except in Anambia borehole. This is because the borehole was completed in the same year it was commissioned.

Tables 7 and 8 show the benefit-cost analysis at different interest factors, varying from $5 \%$ to $11 \%$. Although there was a trend of gradual decrease in value of benefit-cost ratio as the interest factor increased, yet all the values of the benefit-cost ratio were all positive and greater than 1 . Thus, this gives a good indication that the project is viable.

Figure 2 shows the relationship between benefit-cost ratio and interest factor. It can be seen that the values of interest factors considered did not yield any change in benefit-cost ratio values from positive to negative. Thus this shows that for the project analyzed, the benefit-cost ratio was not sensitive to the interest factors considered in the study. 
Table 6: Benefit Data Matrix

\begin{tabular}{llllll}
\hline Year & $\begin{array}{l}\text { Imo-Awka } \\
\text { River }\end{array}$ & $\begin{array}{l}\text { Ifiet } \\
\text { Spring }\end{array}$ & $\begin{array}{l}\text { Okika } \\
\text { River }\end{array}$ & $\begin{array}{l}\text { Anambia } \\
\text { Borehole } \\
\text { Benefit (N) }\end{array}$ & $\begin{array}{l}\text { Total Benefit } \\
\text { Per Year ( })\end{array}$ \\
\hline 1998 & - & $10,677.75$ & - & 891.1 & $11,568.85$ \\
1999 & - & $10,677.75$ & - & 891.1 & $11,568.85$ \\
2000 & $282,760,000$ & $10,677.75$ & $1,057.2$ & 891.1 & $282,772,626.1$ \\
2001 & $282,760,000$ & $10,677.75$ & $1,057.2$ & 891.1 & $282,772,626.1$ \\
2002 & $282,760,000$ & $10,677.75$ & $1,057.2$ & 891.1 & $282,772,626.1$ \\
2003 & $282,760,000$ & $10,677.75$ & $1,057.2$ & 891.1 & $282,772,626.1$ \\
2004 & $282,760,000$ & $10,677.75$ & $1,057.2$ & 891.1 & $282,772,626.1$ \\
2005 & $282,760,000$ & $10,677.75$ & $1,057.2$ & 891.1 & $282,772,626.1$ \\
2006 & $282,760,000$ & $10,677.75$ & $1,057.2$ & 891.1 & $282,772,626.1$ \\
2007 & $282,760,000$ & $10,677.75$ & $1,057.2$ & 891.1 & $282,772,626.1$ \\
2008 & $282,760,000$ & $10,677.75$ & $1,057.2$ & 891.1 & $282,772,626.1$ \\
2009 & $282,760,000$ & $10,677.75$ & $1,057.2$ & 891.1 & $282,772,626.1$ \\
2010 & $282,760,000$ & $10,677.75$ & $1,057.2$ & 891.1 & $282,772,626.1$ \\
2011 & $282,760,000$ & $10,677.75$ & $1,057.2$ & 891.1 & $282,772,626.1$ \\
2012 & $282,760,000$ & $10,677.75$ & $1,057.2$ & 891.1 & $282,772,626.1$ \\
2013 & $282,760,000$ & $10,677.75$ & $1,057.2$ & 891.1 & $282,772,626.1$ \\
2014 & $282,760,000$ & $10,677.75$ & $1,057.2$ & 891.1 & $282,772,626.1$ \\
2015 & $282,760,000$ & $10,677.75$ & $1,057.2$ & 891.1 & $282,772,626.1$ \\
2016 & $282,760,000$ & $10,677.75$ & $1,057.2$ & 891.1 & $282,772,626.1$ \\
2017 & $282,760,000$ & $10,677.75$ & $1,057.2$ & 891.1 & $282,772,626.1$ \\
2018 & $282,760,000$ & $10,677.75$ & $1,057.2$ & 891.1 & $282,772,626.1$ \\
2019 & $282,760,000$ & $10,677.75$ & $1,057.2$ & 891.1 & $282,772,626.1$ \\
2020 & $282,760,000$ & $10,677.75$ & $1,057.2$ & 891.1 & $282,772,626.1$ \\
2021 & $282,760,000$ & $10,677.75$ & $1,057.2$ & 891.1 & $282,772,626.1$ \\
2022 & $282,760,000$ & $10,677.75$ & $1,057.2$ & 891.1 & $282,772,626.1$ \\
\hline
\end{tabular}

Table 7: Analysis at 5\% Interest

\begin{tabular}{lll}
\hline $\begin{array}{l}\text { Undiscounted } \\
\text { Cash Flow }\end{array}$ & $\begin{array}{l}\text { Total } \\
\text { Cost=C+CRC N }\end{array}$ & $\begin{array}{l}\text { Total Benefit } \\
(\mathbb{N})\end{array}$ \\
\hline 1998 & $480,387,775$ & $11,568.85$ \\
1999 & 981,353 & $11,568.85$ \\
2000 & $53,714,907$ & $282,772,626.1$ \\
2001 & $53,714,907$ & $282,772,626.1$ \\
2002 & $53,714,907$ & $282,772,626.1$ \\
2003 & $53,714,907$ & $282,772,626.1$ \\
2004 & $53,714,907$ & $282,772,626.1$ \\
2005 & $53,714,907$ & $282,772,626.1$ \\
2006 & $53,714,907$ & $282,772,626.1$ \\
2007 & $53,714,907$ & $282,772,626.1$ \\
2008 & $53,714,907$ & $282,772,626.1$ \\
2009 & $53,714,907$ & $282,772,626.1$ \\
2010 & $53,714,907$ & $282,772,626.1$ \\
2011 & $53,714,907$ & $282,772,626.1$ \\
2012 & $53,714,907$ & $282,772,626.1$ \\
2013 & $53,714,907$ & $282,772,626.1$ \\
2014 & $53,714,907$ & $282,772,626.1$ \\
2015 & $53,714,907$ & $282,772,626.1$ \\
2016 & $53,714,907$ & $282,772,626.1$ \\
2017 & $53,714,907$ & $282,772,626.1$ \\
2018 & $53,714,907$ & $282,772,626.1$ \\
2019 & $53,714,907$ & $282,772,626.1$ \\
2020 & $53,714,907$ & $282,772,626.1$ \\
2021 & $53,714,907$ & $282,772,626.1$ \\
2022 & $53,714,907$ & $282,772,626.1$ \\
& $1,716,811,994$ & $6,503,805,107$ \\
\hline
\end{tabular}

Table 8: Analysis at 7\% interest

\begin{tabular}{lll}
\hline $\begin{array}{l}\text { Undiscounted } \\
\text { Cash Flow }\end{array}$ & $\begin{array}{l}\text { Total Cost= } \\
\text { C+CRC }(\mathrm{N})\end{array}$ & $\begin{array}{l}\text { Total } \\
(\mathrm{N})\end{array}$ \\
\hline 1998 & $487,026,187$ & $11,568.85$ \\
1999 & 994,914 & $11,568.85$ \\
2000 & $54,457,186$ & $282,772,626.1$ \\
2001 & $54,457,186$ & $282,772,626.1$ \\
2002 & $54,457,186$ & $282,772,626.1$ \\
2003 & $54,457,186$ & $282,772,626.1$ \\
2004 & $54,457,186$ & $282,772,626.1$ \\
2005 & $54,457,186$ & $282,772,626.1$ \\
2006 & $54,457,186$ & $282,772,626.1$ \\
2007 & $54,457,186$ & $282,772,626.1$ \\
2008 & $54,457,186$ & $282,772,626.1$ \\
2009 & $54,457,186$ & $282,772,626.1$ \\
2010 & $54,457,186$ & $282,772,626.1$ \\
2011 & $54,457,186$ & $282,772,626.1$ \\
2012 & $54,457,186$ & $282,772,626.1$ \\
2013 & $54,457,186$ & $282,772,626.1$ \\
2014 & $54,457,186$ & $282,772,626.1$ \\
2015 & $54,457,186$ & $282,772,626.1$ \\
2016 & $54,457,186$ & $282,772,626.1$ \\
2017 & $54,457,186$ & $282,772,626.1$ \\
2018 & $54,457,186$ & $282,772,626.1$ \\
2019 & $54,457,186$ & $282,772,626.1$ \\
2020 & $54,457,186$ & $282,772,626.1$ \\
2021 & $54,457,186$ & $282,772,626.1$ \\
2022 & $54,457,186$ & $282,772,626.1$ \\
& $1,740,536,380$ & $6,503,805,107$ \\
\hline
\end{tabular}


Table 9: Analysis at $8 \%$ Interest

\begin{tabular}{ccc}
\hline $\begin{array}{c}\text { Years of } \\
\text { Undiscounted } \\
\text { Cash Flow }\end{array}$ & $\begin{array}{c}\text { Total Cost }= \\
\text { C+ CRC }(\mathrm{N})\end{array}$ & $\begin{array}{l}\text { Total Benefit } \\
(\mathrm{N})\end{array}$ \\
\hline 1998 & $490,569,664$ & $11,568.85$ \\
1999 & $1,002,153$ & $11,568.85$ \\
2000 & $54,853,402$ & $282,772,626.1$ \\
2001 & $54,853,402$ & $282,772,626.1$ \\
2002 & $54,853,402$ & $282,772,626.1$ \\
2003 & $54,853,402$ & $282,772,626.1$ \\
2004 & $54,853,402$ & $282,772,626.1$ \\
2005 & $54,853,402$ & $282,772,626.1$ \\
2006 & $54,853,402$ & $282,772,626.1$ \\
2007 & $54,853,402$ & $282,772,626.1$ \\
2008 & $54,853,402$ & $282,772,626.1$ \\
2009 & $54,853,402$ & $282,772,626.1$ \\
2010 & $54,853,402$ & $282,772,626.1$ \\
2011 & $54,853,402$ & $282,772,626.1$ \\
2012 & $54,853,402$ & $282,772,626.1$ \\
2013 & $54,853,402$ & $282,772,626.1$ \\
2014 & $54,853,402$ & $282,772,626.1$ \\
2015 & $54,853,402$ & $282,772,626.1$ \\
2016 & $54,853,402$ & $282,772,626.1$ \\
2017 & $54,853,402$ & $282,772,626.1$ \\
2018 & $54,853,402$ & $282,772,626.1$ \\
2019 & $54,853,402$ & $282,772,626.1$ \\
2020 & $54,853,402$ & $282,772,626.1$ \\
2021 & $54,853,402$ & $282,772,626.1$ \\
2022 & $54,853,402$ & $282,772,626.1$ \\
Total & $1,753,200,073$ & $6,503,805,107$ \\
\hline & &
\end{tabular}

Table 10: Analysis at 9\% interest

\begin{tabular}{ccc}
\hline $\begin{array}{c}\text { Undiscounted } \\
\text { Cash Flow }\end{array}$ & $\begin{array}{c}\text { Total Cost }= \\
\text { C+ CRC }(\mathrm{N})\end{array}$ & $\begin{array}{c}\text { Total Benefit } \\
(\mathrm{N})\end{array}$ \\
\hline 1998 & $494,202,848$ & $11,568.85$ \\
1999 & $1,009,575$ & $11,568.85$ \\
2000 & $55,259,650$ & $282,772,626.1$ \\
2001 & $55,259,650$ & $282,772,626.1$ \\
2002 & $55,259,650$ & $282,772,626.1$ \\
2003 & $55,259,650$ & $282,772,626.1$ \\
2004 & $55,259,650$ & $282,772,626.1$ \\
2005 & $55,259,650$ & $282,772,626.1$ \\
2006 & $55,259,650$ & $282,772,626.1$ \\
2007 & $55,259,650$ & $282,772,626.1$ \\
2008 & $55,259,650$ & $282,772,626.1$ \\
2009 & $55,259,650$ & $282,772,626.1$ \\
2010 & $55,259,650$ & $282,772,626.1$ \\
2011 & $55,259,650$ & $282,772,626.1$ \\
2012 & $55,259,650$ & $282,772,626.1$ \\
2013 & $55,259,650$ & $282,772,626.1$ \\
2014 & $55,259,650$ & $282,772,626.1$ \\
2015 & $55,259,650$ & $282,772,626.1$ \\
2016 & $55,259,650$ & $282,772,626.1$ \\
2017 & $55,259,650$ & $282,772,626.1$ \\
2018 & $55,259,650$ & $282,772,626.1$ \\
2019 & $55,259,650$ & $282,772,626.1$ \\
2020 & $55,259,650$ & $282,772,626.1$ \\
2021 & $55,259,650$ & $282,772,626.1$ \\
2022 & $55,259,650$ & $282,772,626.1$ \\
& $1,766,184,365$ & $6,503,805,107$ \\
\hline
\end{tabular}

Conclusion: The overall analysis of the existing water supply situation in Awka has been studied and compared with the present demand and the projected population of the planning area for 25 years design period. Using the calculated per capital water demand, of $0.181 \mathrm{~m}^{3} /$ day.

Table 11: Analysis at $11 \%$ interest

\begin{tabular}{ccc}
\multicolumn{3}{c}{ Table 11: Analysis at 1 interest } \\
\hline Cash Flow & $\begin{array}{c}\text { Total Cost }= \\
\text { C+CRC }(\mathrm{N})\end{array}$ & $\begin{array}{c}\text { Total Benefit } \\
(\mathrm{N})\end{array}$ \\
\hline 1998 & $501,783,197$ & $11,568.85$ \\
1999 & $1,025,060$ & $11,568.85$ \\
2000 & $56,107,252$ & $282,772,626.1$ \\
2001 & $56,107,252$ & $282,772,626.1$ \\
2002 & $56,107,252$ & $282,772,626.1$ \\
2003 & $56,107,252$ & $282,772,626.1$ \\
2004 & $56,107,252$ & $282,772,626.1$ \\
2005 & $56,107,252$ & $282,772,626.1$ \\
2006 & $56,107,252$ & $282,772,626.1$ \\
2007 & $56,107,252$ & $282,772,626.1$ \\
2008 & $56,107,252$ & $282,772,626.1$ \\
2009 & $56,107,252$ & $282,772,626.1$ \\
2010 & $56,107,252$ & $282,772,626.1$ \\
2011 & $56,107,252$ & $282,772,626.1$ \\
2012 & $56,107,252$ & $282,772,626.1$ \\
2013 & $56,107,252$ & $282,772,626.1$ \\
2014 & $56,107,252$ & $282,772,626.1$ \\
2015 & $56,107,252$ & $282,772,626.1$ \\
2016 & $56,107,252$ & $282,772,626.1$ \\
2017 & $56,107,252$ & $282,772,626.1$ \\
2018 & $56,107,252$ & $282,772,626.1$ \\
2019 & $56,107,252$ & $282,772,626.1$ \\
2020 & $56,107,252$ & $282,772,626.1$ \\
2021 & $56,107,252$ & $282,772,626.1$ \\
2022 & $56,107,252$ & $282,772,626.1$ \\
& $1,793,275,050$ & $6,503,805,107$ \\
\hline & &
\end{tabular}

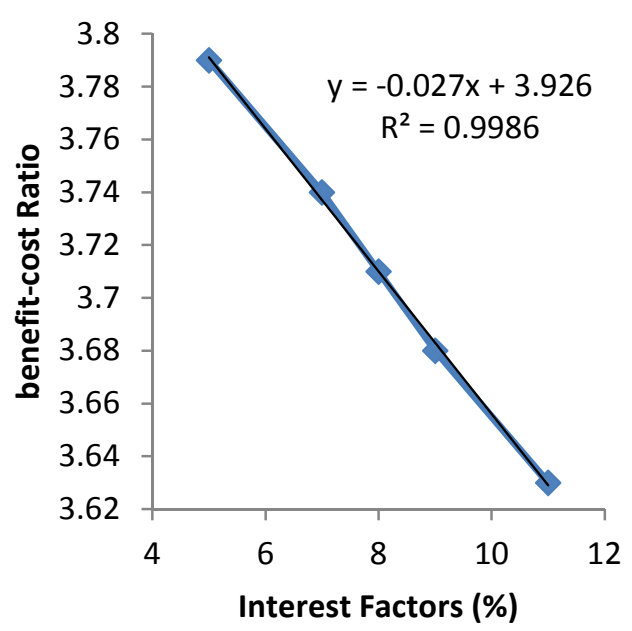

Fig 2: Sensitivity Analysis of Benefit-Cost Ratio

It is observed that the Imo-Awka spring water cannot supply the projected population of Awka with water by the year 2022 It is recommended that a ground reservoir near the intake work be provided to store surplus water between the months of July to November for use between November to March month in addition to using the Okika spring to augument the supply during this dry period of minimum flow. It was also observed that the existing facilities were inadequate and these have been redesigned to meet the 
present and future population needs. The study area has abundant water resources but lack of adequate planning, poverty or lack of funds, absence of hydrologic and hydrogeologica data, lack of trained manpower, absence of water laws, politics, epileptic power supply, lack of proper maintenance or complete absence of it, non-private sector participation are among many problems that have hitherto hindered potable water supply to the area.

\section{REFERENCES}

Ackerman, F. (2006). The Unbearable Lightness of Regulatory Costs. Fordham Urban Law Journal 33 (4): 1071-1096.

Ackerman, F. (2007). Debating Climate Economics: The Stern Review vs. Its Critics. Report to Friends of the Earth. p. 102. http://www.ase.tufts.edu/gdae/Pubs/rp/SternDebat eReport.pdf,

Ackerman, F.; Finlayson, I. (2006). The Economics of Inaction on Climate Change: A Sensitivity Analysis. Climate Policy. 6 (5): 509-526.

Ackerman, F.; Heinzerling, L.(2004). Priceless: On Knowing the Price of Everything and the Value of Nothing. The New Press, N.Y.
Anambra State Gazette (1999). Anambra State Official Gazette.

Cole, M.; Elliott, R. (2007). "Do Environmental Regulations Cost Jobs? An Industry-Level Analysis of the UK," The B.E. Journal of Economic Analysis \& Policy, 7(28): 30-45, available at: http://www.bepress.com/bejeap/vol7/iss1/art28

Emesin, J. (2000). Involving Private Sector Operation in Operation and Management of Anambra State Water Corporation. Journal of Sciences 5(6): 104108.

Okpoka, I.E (1983): "Planning and Management of Water Schemes in Awka Area of Anambra State unpublished Masters' Thesis, Department of Geology Sciences, Nnamdi Azikiwe University, Awka

Pearce, D. (1998). Cost-Benefit Analysis and Environmental Policy. Oxford Review of Economic Policy 14 (4): 84-100. 